\title{
KURIOS
}

(Jurnal Teologi dan Pendidikan Agama Kristen)

Vol. 2, No. 1, Oktober 2014 (32-45)

ISSN 2406-8306 (print)

http://www.sttpb.ac.id/e-journal/index.php/kurios

\section{Keunikan Kekristenan Berakar di Dalam Kesatuannya Dengan Kristus}

\author{
Warisman Harefa \\ Sekolah Tinggi Teologi Pelita Bangsa Jakarta
}

\section{Pendahuluan}

Keunikan tidak berarti menunjuk kepada sesuatu yang aneh (eksentrik). Keunikan kekristenan menunjuk kepada pengajaran finalitas bahwa kekristenan adalah sesuatu yang tidak bisa dibandingkan dengan agama lain. Keunikan dari kekristenan bukan dilihat dari kitabnya, cara ibadah dan penampilan artifisialnya melainkan karena agama ini sebagai hasil dari Wahyu Khusus Allah. Kekristenan bukan berakar dari hasil budaya manusia melainkan berakar di dalam Yesus Kristus, yang adalah Tuhan, yang telah mengalami kesatuan dengan umat-Nya. Konsep keunikan kekristenan ini sangat penting diketahui oleh seluruh orang percaya agar tidak salah mengenal dirinya dalam masyarakat yang majemuk saat ini dan juga tidak menyalahgunakan pengertian keunikan ini.

Beberapa tokoh Alkitab dan juga tokoh Kristen dalam sejaran telah membuktikan hal ini. Pada awal munculnya kekristenan di dunia sudah mengalami banyak penghambatan. Ditengah-tengah segala penghambatan itulah ajaran keunikan kekristenan teruji sehingga bukan saja mereka berkata bahwa Kristen unik melainkan bahwa mereka memberi hidup mereka karena apa yang mereka percayai itu benar. Salah satu peristiwa terjadi ketika Petrus di hadapan para pemimpin-pemimpin agama Yahudi, ditangkap karena mereka memberitakan nama Yesus, rasul-rasul ini diancam agar tidak memberitakan nama itu lagi. Hal yang mengejutkan adalah Petrus dengan berani menjawab mereka, "Kita harus lebih taat kepada Allah dari pada kepada manusia” (Kisah Para Rasul 5:29).

Belajar dari orang-orang percaya yang telah menghidupi keunikan kekristenan ini menuntun kita bahwa klaim keunikan bukan ungkapan semata sebagai atribut keagamaan. Tak dapat dipungkiri, ketika klaim keunikan dianggap sebagai atribut keagamaan banyak orang yang mulai meninggalkan pokok ajaran penting ini karena dianggap membahayakan. 
Bahkan di daerah-daerah yang jumlah pemeluk agama Kristen merasa klaim keunikan ini tidak penting karena sudah merasa aman dan nyaman.

Sesungguhnya juga bahwa klaim keunikan ini bukan ajaran yang mendukung penegakkan superioritas atas agama yang lain. Pengajaran keunikan agama yang salah biasanya membawa kepada radikalisme agama. Ini berhubungan dengan keegoisan komunitas agama yang menganggap dirinya lebih superior dan yang lain inferior. Kelompok ini tidak menolak menggunakan kekerasan atau teror untuk mencapai tujuan agamanya yang diklaim sebagai tujuan suci. Di suatu negara, atau di suatu darerah atau di suatu pulau atau di suatu tempat yang jumlah pemeluk agamanya lebih banyak biasanya klaim keunikan menjadi slogan untuk menekan jumlah pemeluk agama lain yang lebih kecil. Atau bentuk lain yang biasanya terwujud dari sifat superioritas ini adalah pemaksaan iman kepada pemeluk agama lain. Ini berarti tidak menghormati keunikan agama lain yang berbeda dengan dirinya. Maka, klaim keunikan kekristenan tidak bertujuan untuk membuka jalan munculnya keegoisan komunitas Kristen karena jika terjadi hal demikian klaim ini hanya menunjukkan adanya kelemahan dari apa yang kita percayai.

Untuk membuka diri sebagai cara penerimaan yang penuh iman tentang ajaran keunikan kekristenan maka ada baiknya penjelasan ini diawali terlebih dahulu tentang keunikan nama Kristen itu sendiri.

\section{Keunikan Nama Kekristenan}

Nama "Kristen" hanya disebutkan tiga kali dalam seluruh Perjanjian Baru (Kisah Para Rasul 11:26; 26:28; 1Petrus 4:16). Penyebutan nama yang cukup sedikit ini karena orang percaya pada mulanya dipanggil para murid atau jemaat atau saudara. Penyebutan kepada mereka ini nama baru "Kristen" pertama kali ditemukan di dalam Kisah Para Rasul 11:26, "Mereka tinggal bersama-sama dengan jemaat itu satu tahun lamanya, sambal mengajar banyak orang. Di Antiokhialah murid-murid itu untuk pertama kalinya disebut Kristen.” Jadi nama ini tidak muncul sebagai nama yang mereka pikirkan untuk diri mereka namun nama ini muncul sebagai nama julukan oleh orang luar kepada mereka.

Namun kemudian, disepanjang sejarah kekristenan, nama ini mengalami banyak perubahan makna yang dimulai dari nama lelucon (ejekan) kemudian diterima sebagai nama diri, dan berubah menjadi nama organisasi. Maka alangkah baiknya orang Kristen mengenal keunikan nama ini agar mampu menjernihkan keberadaannya di tengah-tengah dunia ini. Penjernihan nama ini sehingga dapat melihat keunikannya hanya dapat terlihat melalui hubungan orang percaya (Kristen) dengan Kristus. 


\section{Dimulai dari nama lelucon}

Nama "Kristen" kemungkinan dari Bahasa Latin, dimana kata benda jamak yang berakhir pada iani (Kristiani). Berdasarkan budaya pada waktu itu, setiap kelompok yang mendukung seorang tokoh maka diberi gelar dengan nama tokoh tersebut yang ditambahi dengan akhiran iani. Contohnya: Agustiani yaitu orang-orang yang mendukung dan dibela Agustus, atau Caesariani yaitu budak-budak yang dibela oleh Kaisar.

Pemberian nama "Kristen" kepada orang-orang percaya pada awalnya, ini terjadi sekitar tahun $40 \mathrm{M}$, adalah julukan (penyebutan) yang diberikan oleh orang-orang lain untuk menunjukkan bahwa orang-orang Kristen adalah pendukung-pendukung Kristus. Julukan ini muncul bukan sebagai pembeda antara orang-orang percaya dengan kelompok lain, melainkan sebuah nama lelucon untuk menghina orang percaya. Nama penghinaan ini karena Yesus yang mereka ikuti sebagai pahlawan adalah tokoh yang mati di salib. Seseorang yang dihukum dengan penyaliban dianggap seorang yang terkutuk, orang berdosa karena salib adalah hukuman yang paling berat pada masa itu. Maka, orang-orang luar karena bencinya pada orang Kristen menghina mereka dengan nama itu. Secara sederhana, mereka sedang berkata kalau orang-orang Kristen adalah kelompok orang-orang yang terkutuk, berdosa seperti pahlawan mereka yang tersalib.

Herodes Agripa adalah seorang raja yang licik dan telah menganiaya orang-orang percaya pun menggunakan nama "Kristen" pada waktu berbicara dengan Paulus, "Hampirhampir saja kau yakinkan aku menjadi orang Kristen!" (Kisah Para Rasul 26:28). Pernyataan Agripa ini sebagai ungkapan penghinaan kepada Paulus terlihat dari reaksinya dalam menjawab Paulus yang begitu dingin. ${ }^{1}$ Penghinaan yang diberikan kepada orang percaya melalui nama ini bukan saja telah menciptakan perbedaan dalam mesyarakat melainkan nama "Kristen" telah dianggap sebagai kelompok yang disejajakan dengan musuh-musuh bangsa Romawi yang harus dihambat dan ditindas.

\section{Diterima sebagai nama diri}

Nama penghinaan itu kemudian diterima oleh orang-orang percaya. Sekitar tahun $60 \mathrm{M}$ nama itu sudah dianggap nama baku dalam masyarakat. Petrus mengingatkan orang-orang percaya untuk tidak malu untuk menderita sebagai orang Kristen, "Tetapi, jika menderita sebagai orang Kristen, maka janganlah ia malu, melainkan hendaklah ia memuliakan Allah dalam nama Kristus itu" (1Petrus 4:16). Nama ini dianggap layak karena memusatkan perhatian kepada unsur yang membedakan, yakni bahwa kelompok ini berpusat pada pribadi

\footnotetext{
${ }^{1}$ Yune Sun Park, Tafsiran Kisah Para Rasul (Batu Malang: YPPII, 2001), 360.
} 
Kristus. Hal ini dijelaskan oleh Groenen O.F.M, “Orang Kristen sendiri lekas mengambil alih sebutan Kristen itu. Dengan demikian mereka mengakui bahwa kesan orang luar itu tepat. Ciri khas orang Kristen ialah hubungannya dengan diri Yesus yang diberi gelar Kristus, bahkan disebut Tuhan". 2

\section{Berubah sebagai nama organisasi}

Memasuki abad ke-20, abad yang disebut-sebuat sebagai kebangkitan agama-agama, konsep kekristenan mengalami pendistorsian. Hal ini diakibatkan karena agama-agama dunia mulai menuntut keunikan dirinya, pada sisi lain kekristenan melihat ajarannya ada yang mirip-mirip dengan ajaran agama lain, yang disebut dengan Golden Rule (Kaidah Kencana), maka beberapa teolog mulai melakukan reinterpretasi terhadap ajarannya. Maka, kekristenan yang semula dihubungkan dengan Kristus dianggap sebagai sikap yang eksklusif dan intoleran. Mereka memikirkan cara adaptasi yang baru sehingga kekristenan pun ikut berubah dan melemahkan pengertian kekristenan menjadi sebuah organisasi agama disamping agamaagama lain.

Dilihat dari ilmu sosiologi dan antropologi, kekristenan adalah salah satu agama diantara agama-agama lain. Dari sisi sosiologi, kekristenan adalah suatu sistem interpretasi terhadap dunia untuk membawa pemahaman diri terhadap pengikutnya tentang peranannya di tengah-tengah alam semesta. Dalam pengertian ini menekankan fungsi kekristenan itu sendiri dalam dunia. apa yang telah disumbangkan oleh agama Kristen dalam masyarakat? Beberapa ahli akhirnya mulai memperlihatkan nilai-nilai kekristenan untuk diintegrasikan kedalam struktur masyarakat, baik dalam bidang sosial, hukum, politik dll.

Dilihat dari sisi antropologi, kekristenan adalah suatu jalan disamping jalan-jalan lain, untuk membawa para pengikutnya bertemu dengan yang ilahi. Dalam agama memang tidak terlepas dari keterhubungannya dengan dunia yang tidak kelihatan (the invisible world), baik itu malaikat atau roh-roh yang dianggap memiliki kuasa yang melebihi manusia. Defenisi ini berdasarkan nilai substansi sehingga kekristenan adalah satu agama dari sekian agama-agama yang beredar di dunia dalam bertemu dengan yang ilahi. Konsep yang ilahi merupakan konsep yang dibawa manusia sejak lahir tentang adanya Penguasa tertinggi di alam semesta. Untuk memuaskan jiwa manusia yang mencari Penguasa tertinggi ini biasanya membutuhkan ritual keagamaan. Dalam ritual keagamaan inilah kekristenan tampil dengan tokoh yang dianggapnya berkuasa, kitab sucinya, tempat ibadahnya dan liturginya.

\footnotetext{
${ }^{2}$ C. Groenen O.F.M, Panggilan Kristen (Yogyakarta: Kanisius, 1979), 9.
} 
Dari beberapa pengertian di atas dapat disimpulkan bahwa agama apapun juga yang ada di muka bumi ini adalah sama. Perbedaan mereka hanya bersifat penampakan saja dan cara menginterpretasikan diri. Setiap agama masing-masing dengan jalannya sendiri mencari yang ilahi dan memikirkan penebusan dan keselamatan manusia apapun bentuk yang dipikirkan. Agama seperti aliran sungai yang berbeda-beda namun berasal dari sumber yang sama.

\section{Pembahasan}

\section{Penjernihan: Kekristenan Berakar di Dalam Kesatuannya Dengan Kristus}

Apa keunikan kekristenan? Unsur manakah yang mempersatukan semua organisasi dari berbagai aliran dalam kekristenan? Jawaban satu-satunya adalah Pribadi Yesus Kristus. Menurut Michael Eaton dalam karyanya Jesus of the Gospel menuliskan, "Seluruh rahasia kehidupan Kristen adalah pandangan kepada Yesus. Kita memandang pribadi-Nya - Dia adalah Allah dan manusia. kita memandang karya-Nya - Dia telah hidup bagi kita dan mati bagi kita. Kita memandang posisi-Nya saat ini - Dia bangkit bagi kita, ditinggikan bagi kita, berdoa bagi kita."3 Dengan tegas Michael Eaton mengatakan bahwa "Kekristenan adalah Kristus." ${ }^{4}$ Kalimat Eaton di atas seakan-akan mengidentikkan Kristus dengan kekristenan. Tetapi gagasan Eaton lebih menunjuk kepada asal mula kekristenan yang berawal di dalam Kristus. Kekristenan berakar, dibangun, di dalam dan melalui Kristus (Kol 2:7). Tanpa Kristus mustahil kekristenan ada karena untuk merekalah Dia datang, mati bangkit, naik ke surga untuk menyediakan tempat bagi mereka.

Beberapa bagian Alkitab menjelaskan tentang perihal hubungan Kristus dengan orang percaya dengan menggunakan berbagai gambaran. Walaupun beberapa gambaran ini mewakilkan hubungan Kristus dan orang percaya, namun sesungguhnya hubungan Kristus dengan umat-Nya jauh lebih besar. Dan hubungan ini seringkali di bahas dalam topik persatuan Kristus dengan orang percaya. Beberapa gambaran yang penting muncul di dalam ajaran Tuhan Yesus tentang pokok anggur dan ranting-rangtingnya, "Tinggallah di dalam Aku dan Aku di dalam kamu . Sama seperti ranting tidak dapat berbuah dari dirinya sendiri, kalau ia tidak tinggal pada pokok anggur, demikian juga kamu tidak berbuah, jikalau kamu tidak tinggal di dalam Aku. Akulah pokok anggur dan kamulah ranting-rantingnya. Barangsiapa tinggal di dalam Aku dan Aku di dalam dia, ia berbuah banyak, sebab di luar Aku kamu tidak dapat berbuat apa-apa" (Yoh 15:4-5). Di tempat lain, hubungan kesatuan ini tergambar di

\footnotetext{
${ }^{3}$ Michael Eaton, Jesus of the Gospel, (Togyakarta: ANDI, 2006), 3

${ }^{4}$ Ibid, 9
} 
dalam Perjamuan Kudus, memakan roti berarti memakan tubuh Kristus (Mat 26:26-28). Dalam surat Paulus, ia menggambarkan hubungan Kristus dengan jemaat-Nya sebagai hubungan suami dengan isteri (Ef 5:32).

Seluruh gambaran di atas menunjuk kepada satu gagasan tentang kesatuan yang permanen. Walaupun demikian, kesatuan yang permanen ini tidak mengandung kesatuan dalam substansi atau penyerapan melainkan tetap terjaga perbedaan individulitas diantara Kristus dan orang percaya. Kesatuan ini sedemikian nyatanya sehingga kesatuan ini tidak hanya dipandang sebagai kesatuan yang ada dalam kesadaran orang percaya belaka (bersifat etis). Juga bukan kesatuan ini hanya dipandang dalam arti kiasan (bersifat simbolis). Yesus sendiri berkata, "Jika seorang mengasihi Aku, ia akan menuruti firman-Ku dan Bapa-Ku akan mengasihi dia dan Kami akan datang kepadanya dan diam bersama-sama dengan dia" (Yoh 14:23). Ungkapan Yesus ini mengandung pengertian tentang "ruang" bahwa orang percaya sebagai suatu wadah dimana Allah Bapa dan Allah Anak akan tinggal di dalamnya. Tetapi harus tetap diingat bahwa pengertian ini tidak menunjuk kepada pengertian material, dalam arti ada yang melingkupi dan dilingkupi, karena Kristus adalah Allah yang tidak terbatas, tidak berubah, dan tidak terbagi-bagi. Untuk memahami kesatuan orang percaya dengan Kristus hanya dapat dimengerti dari beberapa ide-ide penting yang dibicarakan oleh Alkitab.

\section{Kesatuan Dengan Kristus adalah Penyatuan Yang Tak Terpatahkan Antara Allah dan Manusia}

Penjelasan yang tepat dalam mengawali persatuan orang percaya dengan Kristus adalah inkarnasi. Hal ini disebabkan karena inikarnasi merupakan tindakan Pribadi Kedua Allah Tritunggal mengambil natur manusia sejati. Hal ini digenapi melalui proses kehamilan perawan Maria yang tanpa intervensi manusia, melainkan semata-mata karya Roh Kudus. Dengan demikian, Allah Anak telah mengambil natur manusia ke dalam persatuan dengan diri-Nya. Seperti hasil rumusan Calsedon yang mengaku bahwa Kristus memiliki dua natur dalam satu pribadi, natur manusia dan natur ilahi. Kedua natur ini tidak terpisah, tidak terbagi tidak bercampur dan tanpa penggabungan. Namun kedua natur ini dapat dibedakan. Dalam rumusan ini jelas bahwa Allah Anak telah mengenakan natur manusia dalam persatuan dengan Allah sendiri. Persatuan ini suatu persatuan yang tidak terpatahkan dan bersifat permanen. Alkitab menulis bahwa Yesus setelah bangkit tetap mengenakan tubuh natur manusia sempurna bahkan kenaikan-Nya dan bahkan kedatangan-Nya kelak, Yesus Kristus tetap mengenakan natur manusia.

Grudem menjelaskan pengertian yang tepat mengenai rumusan Calsedon bahwa memang rumusan Calsedon tidak memberi kita pengertian secara positif kesatuan natur Allah 
dan natur manusia dalam pribadi Yesus Kristus, tetapi setidak-tidaknya menolong kita untuk menghindari salah pengertian. ${ }^{5}$ Hal yang terutama dijelaskan dari defenisi ini adalah bahwa kesatuan dua natur dalam pribadi Yesus adalah bukan hanya sekedar dua natur berdampingan. Seperti penjelasan Robert Letham, "Natur manusia ini bukan sekedar berdampingan dengan keilahian-Nya, ...karena itu bukan berarti inkarnasi, tetapi sekedar mendiami. Keberdiaman seperti itu tidak dapat menyelamatkan kita. ${ }^{, 6}$ Kesatuan ini ditegaskan dalam kesatuan pribadi walaupun dalam dua natur. Allah Anak bukan mengambil pribadi manusia melainkan natur manusia yang dibawa dalam pribadi Allah Anak.

Ini dapat dipikirkan bahwa natur ilahi sama seperti Allah Bapa. Kristus satu keberadaan dengan Bapa sebagai Tritunggal yang tidak terbagi-bagi. Pribadi yang berbedabeda dalam Tritunggal tidak dapat mengabaikan dan menghapus kesatuan mereka. Bahkan peristiwa inkarnasi Pribadi Kedua pun tidak menghapus kesatuan dalam Tritunggal. Namun demikian, oleh inkarnasi ada hal yang perlu diperhatikan bahwa natur manusia telah dibawa di dalam ke-Allahan. Hal ini secara sederhana dapat digambarkan sebagai berikut: Allah adalah Esa dalam tiga pribadi: Bapa - Anak - Roh Kudus. Ketiga Pribadi dalam Allah Tritunggal tidak terpisah, terbagi, bercampur, dan berubah. Allah Anak berinkarnasi sehingga menyatukan dengan diri-Nya natur manusia secara kekal. Penyatuan natur manusia dalam pribadi Anak tidak mengubah Tritunggal menjadi empat pribadi, tetap tiga pribadi. Juga tidak berarti natur manusia ada di luar kesatuan Tritunggal karena Allah anak adalah satu pribadi yang telah membawa kesatuan permanen dengan natur manusia. Maka, keilahian dan kemanusiaan Kristus adalah untuk selamanya tanpa kemungkinan terjadinya pemisahan di dalam pribadi-Nya yang esa.

Penjelasan hubungan di atas membawa gagasan permanensi dalam kesatuan Allah dan manusia. Suatu kesatuan yang utuh dan tidak terpecahkan untuk selamanya. Penyatuan dengan natur manusia tidak hanya dilihat dari sekedar pelaksanaan penebusan, lebih jauh Kritus membawa penyatuan itu untuk selamanya. Jika tidak demikian inkarnasi akan berhenti sampai di atas salib setelah karya penebusan tergenapi, Ia menanggalkan natur manusia dan mengumumkan bahwa kemenangan telah tergenapi. Tetapi tidak demikian halnya, Kristus terus membawa penyatuan itu sampai selama-lamanya seperti penulis Ibrani berkata, "Yesus Kristus tetap sama, baik kemarin maupun hari ini dan sampai selama-lamanya” (Ibr 13:8). Inkarnansi yang menyikapi gagasan permanensi juga membuka kunci rahasia bahwa Kristus

\footnotetext{
${ }^{5}$ Wayne Grudem, Systematic Theology: An Introduction To biblicl Doctrine (Grand Rapids, Michigan: Zondervan, 1994), 557

${ }^{6}$ Robert Letham, Allah Trinitas: Dalam Alkitab, Sejarah, Theologi, dan Penyembahan (Surabaya: Momentum, 2011), 491
} 
mempersatukan natur manusia dalam diri-Nya untuk mempersatukan kita dengan Allah secara permanen melalui iman kepada-Nya. " Karena anak-anak itu adalah anak-anak dari darah dan daging, maka Ia juga menjadi sama dengan mereka dan mendapat bagian dalam keadaan mereka, supaya oleh kematian-Nya Ia memusnahkan dia, yaitu Iblis, yang berkuasa atas maut" (Ibr 2:14). Kristus yang mengenakan natur manusia untuk menjadi sama dengan manusia yang ditebus-Nya dan mendapat bagian dalam keadaan mereka dapat dipahami dalam pengertian hubungan solidaritas. Seperti manusia adalah sesama bagi orang lain maka hubungan solidaritasantara Kristus dan orang-orang percaya terjalin kesatuan alamiah dan sekaligus representatif. Ide dasarnya adalah inkrnasi Kristus benar-benar mengenakan natur manusia seperti manusia yang akan diwakili-Nya, kecuali dosa. Kemanusiaan yang dipersatukan dengan diri-Nya telah mewakili secara utuh semua orang percaya untuk dipersatukan dengan Allah. Dalam bubungan penting ini, Robert Letham menjelaskan: "Kristus yang dengan-Nya kita ada dalam persatuan memiliki keberadaan yang sama - identik - dengan Allah. Jika mau dinyatakan secara ketat, sesungguhnya kita disatukan dengan kemanusiaan-Nya. Tetapi kemanusiaan-Nya tidak dapat dipisahkan dari keilahian-Nya, karena persatuan hipostatis itu. Maka, persatuan dengan kemanusiaan-Nya adalah persatuan dengan pribadi-Nya. Terlebih lagi, karena pribadi Kristus adalah pribadi Anak yang kekal, kita disatukan dengan Allah. ${ }^{7}$

Penjelasan Letham tersebut telah membuka pengertian kita hubungan kesatuan orang percaya dengan Allah di dalam Kristus. Karena kita telah disatukan dengan Kristus, khususnya kemanusiaan-Nya maka kita telah disatukan dengan keilahian-Nya yang membawa kepada kesatuan dengan Allah Tritunggal. Hubungan ini tidak bisa terpisahkan dan terpatahkan tetapi kesatuan ini tidak menghilangkan perbedaan identitas Pencipta - ciptaan. Persatuan ini tidak meniadakan kemanusiaan kita sebaliknya bahwa kesatuan dengan Allah di dalam Kristus menegaskan kemanusiaan kita yang sesungguhnya, "Seorang pribadi manusia adalah dia yang pada dasarnya terbuka bagi Roh Kudus yang dapat merespons Dia. Atau dengan perkataan lain: seorang pribadi manusia adalah dia yang pada dasarnya dapat berada dalam persekutuan dengan Allah." ${ }^{8}$ Sama seperti natur manusia dalam kesatuan dengan pribadi Kristus tidak terkikis dan terhapus. Persatuan dengan Allah bukan menyangkut penyerapan karena penyerapan membawa pergeseran yang berbahaya, dari Kristus di dalam aku menjadi aku sebagai Allah. Namun, persatuan dengan Allah adalah persatuan di dalam persekutuan pribadi yang intim dan tidak akan terhapus antara Allah dan orang percaya.

\footnotetext{
${ }^{7}$ Robert Letham, 493. 6 Ibid. 496

${ }^{8}$ Ibid. 496
} 
Gambaran yang kuat untuk menjelaskan persekutuan ini bukan menyangkut masalah dimana diri kita melainkan lebih menyangkut apa dan siapa kita. Bersatu dengan Allah di dalam Kristus berarti orang percaya sebagai ciptaan baru telah berbagian di dalam kemuliaan Allah. Jika dikatakan bahwa kita telah berbagian di dalam kemuliaan Allah maka hal ini melebihi relasi-relasi eksternal antara individu yang berbeda. Seperti ucapan Yesus yang menjelaskan betapa mendasarnya persatuan orang percaya dengan Allah, "Jikaseorang mengasihi Aku, ia akan menuruti firman-Ku dan Bapa-Ku akan mengasihi dia dan Kami akan datang kepadanya dan diam bersama-sama dengan dia" (Yoh 14:23).

\section{Kesatuan Dengan Kristus Adalah Jalan Kemanusiaan Mengambil Bagian Dalam Keilahian}

Di atas telah dijelaskan bahwa karena kita telah disatukan oleh Kristus yaitu kemanusiaan-Nya maka kita juga telah disatukan dengan keilahian-Nya sehingga Kristus yang adalah Allah Anak telah membawa natur manusia di dalam kesatuan dengan Allah Tritunggal. Pertanyaannya sekarang bagaimana hubungan kemanusiaan Kristus dan kita orang percaya sehingga orang-orang percaya telah berbagian dalam kesatuan dengan Allah Tritunggal? Kemungkinan yang bisa kita mengerti adalah jika kita telah disatukan dalam kemanusiaan Kristus dan karena kemanusiaan-Nya telah bersatu dengan Pribadi-Nya sebagai Anak Allah sehingga kemanusiaan kita telah berbagian di dalam ke-Allahan, maka keberbagian ini memiliki dimensi yang melebihi persatuan legal dan representatif.

Dalam aspek legal, seluruh kebenaran dan ketaatan Kristus diperhitungkan kepada orang-orang percaya dan dosa-dosa mereka diperhitungkan kepada Kristus, sehingga di hadapan Allah orang-orang percaya dianggap benar oleh Allah. Sedangkan aspek representatif, Allah Anak berinkarnasi mengambil bagian dalam keadaan orang-orang pilihan, yaitu keadaan kita sebagai anak-anak dalam darah dan daging (Ibr 2:14). Karena Kristus telah mengambil bagian dalam keadaan kita maka Ia berdiri sebagai, kurang lebih seperti Adam, kepala perwakilan. Kita dipersatukan dalam ikatan spiritual dan Kristus mewakili satu kesatuan manusia yang akan memperoleh hidup dari pada-Nya.

Alkitab menjelaskan bahwa persatuan Kristus dengan orang-orang percaya jauh lebih luas. Hal ini digambarkan dalam hubungan Kristus sebagai kepala dan jemaat sebagai tubuh (Ef 5:29). Metafora lain terkandung dalam perjamuan kudus, makan roti adalah makan tubuh Kristus dan minum anggur adalah minum darah-Nya (Mat 26:26-29). Bahkan Yesus menghubungkan diri-Nya sendiri dengan para murid, menerima atau menolak mereka berarti menerima atau menolak diri-Nya sendiri dan juga Bapa (Luk 10:16). Dalam tulisan-tulisan 
Paulus gagasan kesatuan ini lebih berkembang. Beberapa rumusan yang dilukiskan oleh Paulus, "di dalam Dia", "di dalam Kristus", "di dalam Kristus Yesus", bahkan pengakuan Paulus yang sangat luar biasa, " Sebab aku telah mati oleh Hukum Taurat untuk Hukum Taurat, supaya aku hidup untuk Allah. Aku telah disalibkan dengan Kristus; namun aku hidup, tetapi bukan lagi aku sendiri yang hidup, melainkan Kristus yang hidup di dalam aku. Dan hidupku yang kuhidupi sekarang di dalam daging, adalah hidup oleh iman dalam Anak Allah yang telah mengasihi aku dan menyerahkan diri-Nya untuk aku" (Gal 2:19-20).

Jika orang percaya dapat mengalami persatuan yang begitu intim dengan Kristus maka kita sedang berbicara mengenai hubungan yang melampaui waktu, yaitu hubungan yang terikat di dalam kekekalan. Bahwa Allah sebelum penciptaan telah memilih sekelompok manusia berdosa untuk diselamatkan. Pemilihan mereka tidak didasarkan kebaikan dalam diri mereka melainkan karena kehendak-Nya sendiri Allah memilih mereka di dalam Yesus. Bila tiba saatnya mereka ini akan dibawa dalam kesatuan dengan Yesus melalui iman, tidak akan terhilang selamanya melainkan menjalani hidup dalam berkat persatuan itu.

Dengan jalan ini, tidak ada yang lain, manusia mengambil bagian dalam kesatuan dengan Allah. Gagasan bahwa inkarnasi adalah jalan bagi kemanusiaan mengambil bagian dalam kesatuan dengan Allah bukan hanya berkenaan dengan pengalaman kita akan Yesus pada saat ini. Jauh ke belakang menembus masa lalu di dalam kekekalan bahwa setiap individu orang percaya telah dipilih oleh Bapa di dalam Yesus yang akan menjadi manusia. Donald Grey Barnhouse menulis seperti yang dikutip Boyce dalam karyanya Dasar-Dasar Iman Kristen: "Dalam dekrit kekal-Nya Allah menetapkan bahwa Ia seharusnya tidak sendirian untuk selamanya, sehingga dari sedemikian banyaknya anak-anak Adam, akan ada sekumpulan yang terdiri dari banyak orang yang akan menjadi anak-anak Allah, orang-orang yang ambil bagian dalam natur ilahi dan dijadikan serupa dengan gambar Tuhan Yesus Kristus. Kawanan ini, sebagai kepenuhan dari Dia yang memenuhi semua di dalam semua, akan menjadi anak-anak melalui kelahiran baru, menjadi anggota-anggota tubuh melalui baptisan Roh Kudus". 9

Pemilihan adalah tindakan Allah sebelum penciptaan dimana Ia memilih sejumlah orang untuk dipersatukan dalam Kristus dan menerima berkat-berkat keselamatan yang mengalir dari karya pengorbanan Kristus, bukan berdasarkan kebaikan melainkan karena kedaulatan-Nya. Sebab di dalam Dia Allah telah memilih kita sebelum dunia dijadikan, supaya kita kudus dan tak bercacat di hadapan-Nya (Ef 1:4). Dalam pemilihan ini

\footnotetext{
${ }^{9}$ James Montgomery Boyce, Dasar-Dasar Iman Kristen (Surabaya: Momentum, 2011), 443
} 
mengandung kesepakatan kekal. Kristus secara sukarela mau menjadi kepala dan jaminan bagi kaum pilihan dengan cara Ia mengambil rupa seperti kita. Kesepakatan ini dapat dikatakan juga bahwa Kristus telah dipilih dalam karya ini (I Pet 1:20). Dalam kesepakatan ini bukan saja dosa dari orang-orang pilihan dijatuhkan atas-Nya untuk meneguhkan kebenaran mereka di hadapan Bapa dengan jalan membayar hukuman dosa mereka, melainkan bahwa Kristus ditetapkan mengenakan natur manusia yang akan ditebus-Nya. Dengan jalan demikian orang-orang pilihan dibebaskan dari perhambaan dosa (Ibr 2:15). Ini sering disebut pembenaran dari sejak kekekalan dan inkarnasi menjadi fakta adanya persatuan riil antara Dia dengan orang-orang pilihan.

Ada hubungan yang sangat erat dan inkarnasi membuka jalan persatuan ini. Inkarnasi memberi arti jalan kemanusiaan mendapat kesatuan dalam keilahian sehingga manusia dibawa ke dalam kesatuan yang tak terpisahkan. Yesus Kristus menjadi manusia dan masuk dalam situasi kita adalah gambar Allah sendiri yang tidak kelihatan (Kol 1:15), dan Ia adalah cahaya kemuliaan Allah (Ibr 1:3), datang untuk mengadakan kontak langsung dengan orangorang yang telah dipilih di dalam Dia. Mereka ini dipulihkan di dalam Dia dan menjadi serupa dengan Dia (Roma 8:29). Jika kita dipulihkan di dalam Dia dan menjadi serupa dengan Dia berarti kita sedang dipulihkan di dalam gambar dan kemuliaan Allah sendiri dan di dalam keserupaan dengan gambar Allah dan kemuliaan Allah. Karena inkarnasi telah membawa kesatuan yang riil antara orang pilihan dengan Kristus dan juga dengan Allah sendiri maka dalam kesatuan ini diberikan hak berbagian dalam relasi pribadi yang hidup dengan Allah. Alkitab memberikan gambaran kesatuan yang hidup ini dalam hubungan Bapa - anak. Hubungan ini bukan hanya sekedar perubahan status dalam kehidupan orang percaya melainkan adanya hubungan yang intim dan kuasa yang yang mengubah sebagai akibat yang ditimbulkannya. J.I Packer menulis: “Anda meringkas seluruh pengajaran Perjanjian Baru dengan satu frasa tunggal, jika Anda berbicara tentang hal itu sebagai penyataan Kebapaan Pencipta yang kudus. Sama halnya Anda meringkas seluruh agama Perjanjian Baru jika Anda menggambarkannya sebagai pengenalan akan Allah sebagai Bapa kita yang kudus. Jika Anda ingin menilai seberapa baik pemahaman seseorang akan kekristenan, temukan seberapa banyak ia melakukan pemikiran tentang menjadi anak Allah, dan menjadi Allah sebagai Bapanya". 10

Perjanjian Baru memberikan tekanan akan hal demikian, karena hubungan baru dimana sekarang Allah menjadi Bapa orang-orang yang disatukan dalam Kristus. Kristus

\footnotetext{
${ }^{10}$ J.I. Packer, Tuntunan Praktis Untuk Mengenal Allah (Yogyakarta: ANDI, 2002), 255
} 
adalah Anak Allah yang kekal dan setiap orang yang disatukan dengan Kristus akan menjadi anak-anak Allah sebagai hasil adopsi. Dengan demikian, menjadi anak Allah bukan status universal sebagai hak prerogatif setiap orang melalui kelahiran pada umunya melainkan karunia supranatural yang diterima setiap orang sebagai hasil kesatuannya dengan Kristus. Dikatakan sebagai karunia suprantural karena itu sepenuhnya karya Allah dalam hidup kita, "Tetapi semua orang yang menerima-Nya diberinya kuasa supaya menjadi anak-anak Allah, yaitu mereka yang percaya dalam nama-Nya; orang-orang yang diperanakkan bukan dari darah atau daging, bukan pula secara jasmani oleh keinginan seorang laki-laki, melainkan dari Allah" (Yoh 1:12-13).

Hal yang menarik adalah bahwa hubungan baru dimana Allah menjadi Bapa dan orang-orang percaya sebagai anak merupakan hubungan perjanjian Allah sendiri. Dari Perjanjian Lama Allah telah memberitakan hal ini melalui panggilan-Nya kepada Israel sebagai anak-Nya, yaitu keturunan Abraham (Kel 4:22-23). Perjanjian Baru menyingkapkan hal ini bahwa yang dimaksud keturunan Abraham bukanlah yang lahir secara jasmani melainkan mereka yang adalah milik Kristus, telah dipersatukan dengan Kristus (Gal 3:29). Hubungan perjanjian ini berisikan bahwa Allah telah mengikat diri-Nya sendiri kepada umatNya untuk menjadi Bapa bagi mereka dan mereka menjadi anak-anak-Nya sendiri, keturunanNya sendiri. Ini adalah suatu perjanjian keluarga bahwa orang percaya memiliki keberanian karena iman kepada Kristus memanggil Allah sebagai Bapa-Nya.

Jauh ke dalam batin orang-orang percaya, kesatuan dengan Allah sebagai keluarga, telah membawa penanaman kehidupan ilahi ketika Roh Kristus datang dan tinggal dalam hati orang percaya. Ini adalah penyatuan dan sekaligus berbagian dalam kehidupan baru untuk menjadi segambar dengan Kristus. Inkarnasi yang telah membawa jalan penyatuan kemanusiaan berbagian di dalam ke-Allahan adalah suatu penyatuan yang penuh berkat. Kristus memberikan Roh-Nya yaitu Roh Kudus untuk membawa penyatuan ini lebih hidup dan menjadi sumber serta kekuatan sebagai hidup yang terberkati. Tepat sekali penjelasan Boice mengenai hidup yang berbagian dalam kehidupan ilahi.

Dalam suatu cara yang analogis, kita mengalami penanaman kehidupan ilahi dalam kita ketika Roh Kristus datang untuk tinggal dalam hati kita. Kita dapat berkata, seperti Maria, "Bagaimana hal mungkin terjadi, sebab aku sendiri tidak mempunyai kuasa untuk memperanakkan kehidupan ilahi?" Tetapi jawaban itu ada dalam kata-kata sang malaikat, "Roh Kudus akan turun atasmu dan kuasa Allah Yang Mahatinggi akan menaungi engkau; sebab itu anak yang akan kau lahirkan itu akan disebut kudus, Anak Allah" (Luk1:35). Kita tidak menjadi ilahi seperti keyakinan beberapa agama Timur. Tetapi dalam pengertian tertentu 
kehidupan Allah menjadi hidup di dalam kita sehingga kita layak disebut putra dan putri Allah. $^{11}$

Persatuan dengan Kristus adalah jalan memasuki kehidupan yang berbagian dengan Allah. Seperti penjelasan Boice diatas, inkarnasi adalah jalan mempersatukan orang-orang pilihan kepada Allah melalui Roh-Nya yang diam dalam kita sehingga kesatuan itu mempengaruhi kehidupan orang percaya, kuasa yang bekerja, sehingga kehidupan Allah menjadi hidup dalam kehidupan kita. Maka oleh Roh itu kita berani berseru kepada Allah: ya Abba, ya Bapa (Rom 8:15).

\section{Kesimpulan}

Hal yang disaksikan oleh Alkitab betapa eratnya kesatuan orang percaya dengan Kristus sebagai akar dari ajaran keunikan kekristenan, sesungguhnya dapat memberi penjelasan yang akurat bahwa klaim ini bukan hanya sekedar pemanis untuk menarik orang lain masuk kekristenan. Tetapi disinilah awal dimulainya kejujuran dalam hidup beragama. Klaim keunikan merupakan sikap keterbukaan tentang keyakinan yang dipercayai adalah sungguh benar dan telah teruji. Keyakinan akan keunikan apa yang dipercayai sekaligus menuntun pada kerelaan untuk siap diuji tentang keyakinannya dan terbukti dapat dipertanggungjawabkan. Dapat disimpulkan bahwa inilah tujuan dari keunikan kekristenan. Bukan hanya sekedar berkata, "kita berbeda" melainkan bahwa kekristenan adalah milik Kristus dan Kristus adalah milik Allah sehingga kekristenan adalah milik Allah. Karena kekristenan adalah milik Allah maka klaim ini merupakan deklarasi iman semua orang-orang percaya kepada Kristus.

Ini semata-mata bukan hanya sekedar ungkapan yang dianggap benar karena kebenaran keunikan kekristenan bukan pada kata-kata atau pembelaan melainkan kepada Kristus yang adalah Kebenaran. Ini adalah kebenaran Pribadi, yang ditegaskan oleh Yesus sendiri, "Aku jalan, kebenaran, dan hidup" (Yoh 14:6). Karena pribadi-Nya sendiri adalah kebenaran maka seluruh tindakan dan perkataan-Nya adalah benar. Maka, pada waktu memberitakan klaim keunikan kekristenan ini berarti orang-orang percaya telah memberitakan Kristus yang adalah satu-satunya kebenaran karena Kristus telah membenarkan kita di hadapan Allah sebagai hasil tebusan-Nya melalui pengorbanan-Nya di atas kayu salib.

\footnotetext{
${ }^{11}$ James Montgomery Boyce, 444
} 


\section{Daftar Pusataka}

Boyce, James Montgomery. Dasar-Dasar Iman Kristen, Surabaya: Momentum, 2011 Eaton, Michael. Jesus of the Gospel, Yogyakarta: ANDI, 2006

Grudem, Wayne. Systematic Theology: An Introduction To biblicl Doctrine, Grand Rapids, Michigan: Zondervan, 1994

Letham, Robert. Allah Trinitas: Dalam Alkitab, Sejarah, Theologi, dan Penyembahan.

Surabaya: Momentum, 2011

O.F.M, C Groenen. Panggilan Kristen, Yogyakarta: Kanisius, 1979

Packer, J.I. Tuntunan Praktis Untuk Mengenal Allah, Yogyakarta: ANDI, 2002

Park, Yun Sun. Tafsiran Kisah Para Rasul. Batu Malang: YPPII, 2001 